SHORT COMMUNICATION

\title{
New records of Leptospira spp. in wild marsupials and a rodent in the eastern Brazilian Amazon through PCR detection
}

\author{
Katarine de SOUZA ROCHA ${ }^{1}$, Gleiciane SCHUPP DE SENA MESQUITA ${ }^{1}$, Maeli Fernanda SILVA \\ FERREIRA ${ }^{1}$, Flávia de Nazaré LEITE BARROS², Renata Cecília Soares de Lima MACEDO ${ }^{3}$, Elane de \\ ARAÚJO SARAIVA ${ }^{4}$, Ana Cristina MENDES-OLIVEIRA ${ }^{3}$, Valíria DUARTE CERQUEIRA ${ }^{5}$, Alessandra \\ SCOFIELD ${ }^{2}$, Gustavo GOES CAVALCANTE² ${ }^{2}$ Isis ABEL ${ }^{4}$, Carla Cristina GUIMARÁES DE MORAES ${ }^{1 *}$ (] \\ Universidade Federal do Pará (UFPA), Instituto de Medicina Veterinária, Laboratório de Zoonoses e Saúde Pública, Castanhal, PA, Brazil \\ Universidade Federal do Pará (UFPA), Instituto de Medicina Veterinária, Laboratório de Parasitologia Animal, Castanhal, PA, Brazil \\ Universidade Federal do Pará (UFPA), Instituto de Ciências Biológicas, Laboratório de Zoologia e Ecologia deVertebrados, Belém, PA, Brazil \\ ${ }^{4}$ Universidade Federal do Pará (UFPA), Instituto de Medicina Veterinária, Laboratório de Epidemiologia e Geoprocessamento, Castanhal, PA, Brazil \\ Universidade Federal do Pará (UFPA), Instituto de Medicina Veterinária, Laboratório de Patologia Animal, Castanhal, PA, Brazil \\ * Corresponding author:cc_moraes@yahoo.com; (1D https://orcid.org/0000-0001-8616-648X
}

\begin{abstract}
We analyzed the presence of Leptospira spp. in liver and kidney tissue of wild marsupials and rodents trapped in a periurban forest in the eastern Brazilian Amazon. We examined 25 individuals of four marsupial and seven rodent species for the presence of the 16S rRNA gene of Leptospira in the DNA extracted from 47 liver and kidney tissue samples using PCR. We detected positive samples in $12 \%(3 / 25)$ of the individuals, in kidney fragments of two marsupial species (Didelphis marsupialis and Marmosops pinheiroi) and in a liver fragment of one rodent species (Echimys chrysurus). These are the first records of Leptospira spp. in M. pinheiroi and E. chrysurus and it is the first molecular survey of marsupials and rodents in the Brazilian Amazon.
\end{abstract}

KEYWORDS: Didelphimorphia, Rodentia, live traps, kidney, liver, 16S rRNA

\section{Novos registros de Leptospira spp. em marsupiais e um roedor silvestres na Amazônia Oriental por detecção por PCR}

\section{RESUMO}

Analisamos a presença de Leptospira spp. em tecido hepático e renal de marsupiais e roedores silvestres capturados em uma floresta periurbana no leste da Amazônia brasileira. Foram examinados 25 indivíduos de quatro espécies de marsupial e sete de roedor quanto à presença do gene $16 \mathrm{~S}$ rRNA de Leptospira no DNA extraído de 47 amostras de tecido hepático e renal usando PCR. Detectamos amostras positivas em 12\% (3/25) dos indivíduos, em fragmentos renais de duas espécies de marsupial (Didelphis marsupialis e Marmosops pinheiroi) e em um fragmento hepático de uma espécie de roedor (Echimys chrysurus). Estes são os primeiros registros de Leptospira spp. em M. pinheiroi e E. chrysurus, e é o primeiro levantamento molecular de marsupiais e roedores na Amazônia brasileira.

PALAVRAS-CHAVE: Didelphimorphia, Rodentia, armadilhas, rim, fígado, 16S rRNA

Leptospirosis is a globally distributed zoonosis and is known to have domestic and wild animal species as reservoirs, mainly small mammals such as rodents and marsupials (Adler and De La Peña Moctezuma 2010). In the Brazilian Amazon, the intensification of land demand generates the emergence and expansion of urban borders, contributing to the increase in deforestation (Ribeiro et al. 2018). Deforestation generates environmental changes and ecological disturbances that facilitate contact with wild species, favoring the incidence of diseases transmitted by animals (Saccaro Junior et al. 2015). Serological surveys have also suggested that these animals might be potential reservoirs of Leptospira spp. (ValbuenaTorrealba and Péfaur-Veja 2015; Paixão et al. 2014; Silva et al. 2013; Ruiz-Piña et al. 2002).

In the Amazon region, few studies have investigated the presence of Leptospira in marsupials and rodents. Burnnel et al. (2000) identified DNA from Leptospira spp. in kidney 
samples from $20 \%$ of rodents and $39 \%$ of marsupials sampled in Iquitos, in the Peruvian Amazon, and identified DNA from pathogenic leptospires in Philander sp., Marmosops bishopi (Pine, 1981) and Marmosops noctivagus (Tschudi, 1845), suggesting that marsupials are the most significant hosts for the potential transmission of pathogenic leptospires to humans in the region.

There are few data on the infection of wild species by leptospires in the Brazilian Amazon. Lins and Lopes (1984) identified isolates of serovar Ballum in bacterial cultures of renal tissue of two rodents (Proechimys sp.) and a marsupial (Didelphis marsupialis Linnaeus, 1758), and two unidentified isolates in rodents and four in marsupials. Mesquita et al. (2018) reported a prevalence of $36.8 \%$ of seropositive $D$. marsupialis, Caluromys sp. and Marmosa murina (Linnaeus, 1758) for antibodies to serovars Icterohaemorrhagiae, Panama and Nupezo. Here, we report the first data on detection of Leptospira spp. in wild marsupials and rodents from the state of Pará using PCR.

Small mammal trapping was carried out in a secondary forest fragment located in the Expedito Ribeiro settlement (1¹7'06.76”'S, 48¹5'44.04'W), in the municipality of Santa Bárbara, Pará state, in the eastern Brazilian Amazon (Figure 1). The climate in the region is hot and humid, with a relative air humidity of approximately $85 \%$, with average temperature around $26^{\circ} \mathrm{C}$ throughout the year and annual rainfall exceeding $2,550 \mathrm{~mm}$, with more frequent rains from January to June (Santos and Jardim 2006).
Animals were captured using baited Sherman, Tomahawk and pitfall traps during at least 10 consecutive nights in two field expeditions in October 2015 and April 2016. Captured marsupials and rodents were first anesthetized and then euthanized as recommended by the National Council for Animal Experimentation Control (CONCEA). Small mammal sampling was authorized by Instituto Brasileiro do Meio Ambiente e Recursos Naturais Renováveis - IBAMA (37174-1) and the ethics committee on animal use of the Evandro Chagas Institute - CEUA/IEC (protocol 028/2014).

Pregnant or lactating females and young were excluded and released at the place of capture. Euthanaized animals were necropsied in locu to collect fragments of liver and kidney. The tissue samples were stored in $1.5 \mathrm{~mL}$ sterile microtubes in a nitrogen canister for transport to the Zoonosis and Public Health Laboratory of the Federal University of Pará (UFPA). The species were identified based on morphometric measurements and cranial analysis by expert taxonomists from Universidade Federal do Pará - UFPA and Museu Paraense Emílio Goeldi.

The extraction of DNA from the liver and kidney samples was performed with the IllustraTM Tissue and Cell Prep Mini Spin kit (GE Healthcare ${ }^{\odot}$ ). DNA was detected using the primers described by Mérien et al. (1992), (5'GGCGGCGCGTCTTAAACATG3') and (5'TTCCCCCCATTGAGCCAAGATT3'), which amplify 331 base pairs of the Leptospira spp. 16S rRNA gene. Amplification was performed by polymerase chain reaction
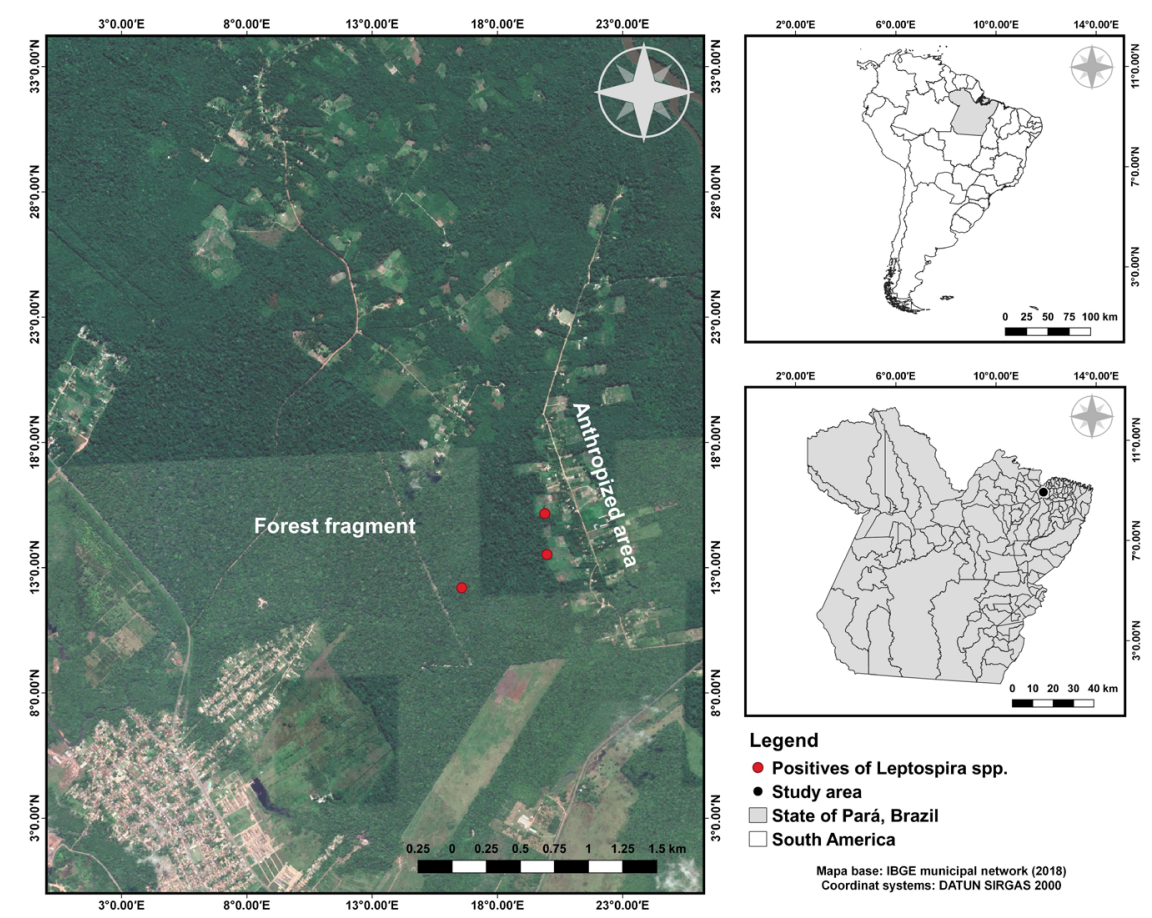

Figure 1. Location of Pará state in Brazil and South America, and of the study area within Pará state. The satellite image shows the sampled forest fragment and nearby urban areas. Red circles indicate the capture site of the rodent and marsupials positive for Leptospira spp. This figure is in color in the electronic version. 
(PCR). The PCR mixture contained $2.5 \mu \mathrm{L}$ buffer $(50 \mathrm{mM}$ $\mathrm{KCl}$ and $10 \mathrm{mM}$ Tris- $\mathrm{HCl}, \mathrm{pH} 8.0), 1.0 \mu \mathrm{L} \mathrm{MgCl}_{2}(1.5$ $\mathrm{mM}), 1.0 \mu \mathrm{L}$ dNTP solution $(1.0 \mathrm{mM}), 0.3 \mu \mathrm{L}$ Taq DNA polymerase (Ludwig), $1 \mu \mathrm{L}$ of each oligonucleotide primer ( $2.5 \mathrm{pmol}), 5 \mu \mathrm{L}$ DNA template, and $13.2 \mu \mathrm{L}$ ultrapure water in a final volume of $25 \mu \mathrm{L}$.

The amplification reactions were each carried out with a positive control of $25 \mathrm{ng} \mathrm{\mu l}^{-1} \mathrm{DNA}$ from Leptospira interrogans serovar canicola and a negative control from a tissue sample of the rodent species Rattus norvegicus (Berkenhout, 1769) free of Leptospira from an authorized vivarium, and ultrapure nuclease-free water was used as a contamination control.

The thermal cycling steps in PCR included an initial denaturation at $94^{\circ} \mathrm{C}$ for $3 \mathrm{~min}$, followed by 35 cycles of denaturation at $94^{\circ} \mathrm{C}$ for $1 \mathrm{~min}$, annealing at $59^{\circ} \mathrm{C}$ for 1.5 min, and extension at $72^{\circ} \mathrm{C}$ for $2 \mathrm{~min}$, and a final extension at $72^{\circ} \mathrm{C}$ for $10 \mathrm{~min}$. All amplification reactions were performed in a Veriti" 96-Well Thermal Cycler (Applied Biosystems). The PCR products were analyzed by electrophoresis on a $1.5 \%$ agarose gel; the gel was stained with a safe dye (KASVI') and visualized under ultraviolet light on a transilluminator coupled to a photo-documentation system (Gel Doc ${ }^{\mathrm{TM}} \mathrm{XR}+$ Imaging System, BioRad).

We analyzed 47 liver and kidney samples from 11 marsupials belonging to four species and 14 rodents belonging to seven species, including a synanthropic rodent (Rattus rattus), suggesting that these animals typically from urban surroundings come into contact with wild animals in the study area, which may pose a risk of agent transmission (Table 1).

Leptospira spp. DNA was detected in $12 \%(3 / 25)$ of the individuals. The rate of infection was higher in the marsupials, with $18.2 \%(2 / 11)$ infected animals as compared to the rodents, with 7.2\% (1/14) infected animal (Table 1). Leptospira spp. DNA was present in the kidney of one individual each of Didelphis marsupialis and Marmosops pinheiroi (Pine, 1981) (Didelphidae) captured on the edge of the forest fragment, and the liver of the only individual of Echimys chrysurus (Zimmermann, 1780) (Echimydae) captured inside the forest fragment (Table 1; Figure 1).

This is the first report of detection of Leptospira DNA in marsupials in the Brazilian Amazon, which agrees with the findings of Burnell et al. (2000), who detected Leptospira spp. DNA in kidney samples of marsupials from the Peruvian Amazon using G1/G2 primers and identified infection by pathogenic leptopsires through the $23 \mathrm{~S}$ rRNA gene in three marsupial species (Philander sp., Marmosops bishopi and Marmosops noctivagus). Didelphis marsupialis is the marsupial most frequently associated with Leptospira. The species was tested positive for serovar ballum isolates by Lins and Lopes (1984) in the Brazilian Amazon, serovars szwajizak and icterohaemorrhagiae by Rosa et al. (1975) in southeastern Brazil, and serovars Djasiman, Sejroe and Cynopteri by
Hidalgo and Sulzer (1984) in Peru. To the best of our knowledge, this is the first report of infection by Leptospira in Marmosops pinheiroi.

Antibodies against Leptospira spp. had already been detected in D. marsupialis, Caluromys sp. and Marmosa murina in the same region in the state of Pará (Mesquita $e t$ al. 2018), which, together with our detection of Leptospira DNA in kidney samples from D. marsupialis and M. pinheiroi, suggests that marsupials are potential reservoirs of the agent at the region.

This is also the first report of infection by Leptospira spp. in Echimys chrysurus. Vieira et al. (2018) reported an average infection rate of $20 \%$ among several species of wild rodents in Latin America, not including the species identified as positive in the present study, suggesting that more studies are necessary to evaluate the role of wild rodents as a reservoir of Lesptospira. Bacterial DNA in rodent blood and kidney samples has also been found in the Mata Atlântica biome in Brazil (Paixão $e t$ al. 2014; Vieira et al. 2019)13 rats were captured at seven locations of the Centre for the Conservation of Wild Fauna (CCWF. Leptospira DNA was reported in 6\% of wild small mammals captured in three forest areas in Germany (Obiegala et al. 2016), in $20.4 \%$ of rodents captured in urban and rural areas in Chile (Muñoz-Zanzi et al. 2014) and in 13\% of wild rodents captured in Malaysia (Latifah et al. 2012).

Unfortunately, our small sample size does not allow for reliable inferences regarding prevalence of Leptospira spp. in the community of arboreal mammals in the study area. The low number of animals captured was probably due to the abundance of food in the forest, which made the bait in the

Table 1. Species of marsupial and rodent captured in a forest fragment in the municipality of Santa Bárbara, Pará state (Brazilian Amazon) for detection of Leptospira spp. DNA in tissue samples. $\mathrm{N}=$ number of individuals captured. Prevalence is indicated for positive cases.

\begin{tabular}{lcc}
\hline Sampled species & N & Prevalence \\
\hline Rodentia & 3 & Negative \\
\hline Oecomys cf. bicolor & 6 & Negative \\
\hline Oecomys paricola & 1 & Negative \\
\hline Guerlinguetus cf. gilvigularis & 1 & $01 / 01(100 \%)$ \\
\hline Echimys chrysurus & 1 & Negative \\
\hline Neacomys sp. & 1 & Negative \\
\hline Nectomys cf. rattus & 1 & Negative \\
\hline Rattus rattus & & \\
\hline Didelphimorphia & 6 & $01 / 06(16.4 \%)$ \\
\hline Marmosops pinheiroi & 3 & $01 / 03(33.3 \%)$ \\
\hline Didelphis marsupialis & 1 & Negative \\
\hline Philander opossum & 1 & Negative \\
\hline Metachirus nudicaudatus & 25 & $3 / 25(12 \%)$ \\
\hline Total & & \\
\hline
\end{tabular}


traps less attractive. In addition, the concentration of DNA amplified from the PCR-positive samples was not sufficient for sequencing and, therefore, the Leptospira species infecting the animals could not be identified. Further research should confirm whether marsupials and rodents in the region carry pathogenic forms of Leptospira and determine the prevalence and circulation dynamics of this pathogen among wildlife in the region.

\section{ACKNOWLEDGMENTS}

The authors are grateful for the support of Pró-Reitoria de Pesquisa e Pós-Graduação (Propesp-UFPA), Fundação de Amparo e Desenvolvimento da Pesquisa - FADESP (\# 02/2017) of Programa de Apoio à Publicação Qualificada (PAPQ), Coordenação de Aperfeiçoamento de Pessoal de Nivel Superior (CAPES) or financing the research through the call for proposals Pró-Amazônia \# 3286/2013 and granting a scholarship to the first author, and Conselho Nacional de Desenvolvimento Científico e Tecnológico (CNPq) for the research productivity grants to some co-authors.

\section{REFERENCES}

Adler, B.; De La Peña Moctezuma, A. 2010. Leptospira and leptospirosis. Veterinary Microbiology, 140: 287-296.

Bunnel, J.E.; Hice, C.L.; Watts, D.M.; Montrueil, V.; Tesh, R.B.; Vinetz, J.M. 2000. Detection of pathogenic Leptospira spp. infections among mammals captured in the Peruvian Amazon basin region. The American Journal of Tropical Medicine and Hygiene, 63: 255-258.

Hidalgo, J.L.; Sulzer, K. 1984. Six New Leptospiral Serovars Isolated from Wild Animals in Peru. Journal of Clinical Microbiology, 19: 944-945

Latifah, I.; Rahmat, M.; Hayarti, K.B.; Paramasvaran, S.; Azizah, M.R.; Imran, M.D.; et al. 2012. Prevalence of leptospiral DNA among wild rodents from a selected area in Beguk Dam Labis, Segamat, Johor, Malaysia. Malaysian Jounal of Pathology, 34: 157-159.

Lins, Z.C.; Lopes, M.L. 1984. Isolation of Leptospira from wild forest animals in Amazonian Brazil. Transactions of the Royal Society of Tropical Medicine and Hygiene, 78: 124-126

Mérien, F.; Amouriaux, P.; Perolat, P.; Baranton, G.; Girons, I.S. 1992. Polymerase chain reaction for detection of Leptospira in clinical samples. Journal of Clinical Microbiology, 30: 2219-2224.

Mesquita, G.S.S.; Rocha, K.S.; Monteiro, T.R.M.; Rosário, M.K.S.; Baia, I.W.M.; Pereira, H.S.; et al. 2018. Detection of antibodies against Leptospira spp in free-living marsupials caught in the Eastern Amazon. Revista da Sociedade Brasileira de Medicina, 51: 368-371.

Muñoz-Zanzi, C.; Mason, M.; Encina, C.; Gonzalez, M.; Berg, S. 2014. Household characteristics associated with rodent presence and Leptospira infection in rural and urban communities from southern Chile. American Journal Tropical Medicine Hygiene, 90: 497-506.

Obiegala, A.; Woll, D.; Karnath, C.; Silaghi, C.; Schex, S.; Eßbauer, S.; et al. 2016. Prevalence and genotype allocation of pathogenic Leptospira species in small mammals from various habitat types in Germany. PLoS Neglected Tropical Diseases, 10: e0004501.

Paixão, M.S.; Alves-Martin, M.F.; Tenório, M.S.; Starke-Buzetti, W.A.; Alves, M.L.; Silva, D.T.; et al. 2014. Serology, isolation, and molecular detection of Leptospira spp. from the tissues and blood of rats captured in a wild animal preservation centre in Brazil. Preventive Veterinary Medicine, 115: 69-73.

Ribeiro, R.M.; Amaral, S.; Monteiro, A.M.V.; Dal'Asta, A.P. 2018. Os processos de urbanização e conversão florestal na Amazônia paraense - um estudo multiescalar. Revista Brasileira de Estudos de População, 35: e0068

Ruiz-Piña, H.A.; Puc-Franco, M.A.; Flores-Abuxapqui, J.; VadoSolís, I.; Cárdenas-Marrufo, M.F. 2002. Isolation of Salmonella enterica and serologic reactivity to Leptospira interrogans in opossums (Didelphis virginiana) from Yucatán, México. Revista do Instituto de Medicina Tropical de São Paulo, 44: 235-237.

Saccaro Junior, N.L.; Mation, L.F.; Sakowski, P.A.M. 2015. Impacto do desmatamento sobre a incidência de doenças na Amazônia. Texto para Discussão, IPEA 2142: 1-46.

Santa Rosa, C.A.; Sulzer, C.R.; Giorgi, W.; Silva, A.S.; Yanaguita, R.M.; Lobao, A.O. 1975. Leptospirosis in wildlife in Brazil: isolation of a new serotype in the pyrogenes group. American Journal of Veterinary Research, 36: 1363-1365.

Santos, G.C.; Jardim, M.A.G. 2006. Florística e estrutura do estrato arbóreo de uma floresta de várzea no município de Santa Bárbara do Pará, Estado do Pará, Brasil. Acta Amazonica, 36: 437-446.

Silva, F.J.; Silva, T.R.; Silva, G.C.P.; Santos, C.E.P.; Alves Júnior, J.R.F.; Mathias, L.A. 2013. Isolamento de Leptospira borgpetersenii em Didelphis albiventris sinantrópicos em Jaboticabal, São Paulo, Brasil. Brazilian Journal of Veterinary Research and Animal Science, 50: 457-461.

Valbuena-Torralba, C.; Péfaur-Veja, J.E. 2015. Determinación de leptospirosis en roedores y marsupiales de la región sur del lago de Maracaibo, estado Mérida, Venezuela. Revista Cientifica, 25: 193-199.

Vieira, A.S.; Di Azevedo, M.I.N.; D’Andrea, O.S.; Val Vilela, R.; Lilenbaun, W. 2019. Neotropical wild rodents Akodon and Oligoryzomys (Cricetidae: Sigmodontinae) as important carriers of pathogenic renal Leptospira in the Atlantic forest, in Brazil. Research in Veterinary Science, 124: 280-283.

Vieira, A.S.; Pinto, P.S.; Lilenbaum, W. 2018. A systematic review of leptospirosis on wild animals in Latin America. Tropical Animal Health and Production 50: 229-238.

RECEIVED: 23/09/2019

ACCEPTED: 06/08/2020

ASSOCIATE EDITOR: Rodrigo R. do Valle 